\title{
Africa and UN Peace Operations: Implications for the Future Role of Regional Organisations
}

\author{
Cedric de Coning
}

\section{INTRODUCTION}

Over the past decade and a half, Africa has developed a significant peace operations capacity. This is reflected in the number of peacekeepers African countries contribute to African-led and United Nations (UN) peace operations. African countries contributed only 10,000 troops to UN peacekeeping operations in 2000, when the African Union (AU) was established (Lotze 2013). Today, African countries contribute about $50 \%$ of the UN's approximately 100,000 peacekeepers. ${ }^{1}$ This means that Africa has now replaced South East Asia as the largest regional contributor to UN peace operations. Since the AU was launched, it has deployed

\footnotetext{
${ }^{1}$ Peacekeeping statistics are constantly changing, both in the short term due to routine rotations, and longer term due to the kind of changes addressed in this paper. The UN provides monthly updates at (UN 2018).
}

C. de Coning $(\bowtie)$

Norwegian Institute of International Affairs (NUPI), Oslo, Norway

e-mail: cdc@nupi.no

(C) The Author(s) 2019

C. de Coning and M. Peter (eds.), United Nations

Peace Operations in a Changing Global Order, https://doi.org/10.1007/978-3-319-99106-1_11 
eight peace operations of its own, including to Burundi (AMIB), the Central African Republic (MISCA), the Comoros (AMISEC and MAES), Mali (AFISMA), Somalia (AMISOM) and Sudan (AMIS I and II). In addition, it has provided support to ad hoc regional security coalitions against the Lord's Resistance Army (LRA), Boko Haram and instability in the Sahel region. In total, African countries contributed approximately 85,000 military, police and civilian personnel to UN and African-led peace operations in 2018. The main reason why Africa's peace operations capacity has significantly increased over the past decade and a half is because the AU and the sub-regional organisations in Africa, with significant support from international partners, have invested in establishing and developing the African Standby Force. This project has generated political support in Africa and internationally for a significantly scaled-up African role in peace operations on the African continent. It has been successful in focussing the support of international partners, including the UN, on building African peace operations capacities. The success of this project to date has boosted the confidence of the AU and the sub-regional organisations, and today they are playing a much more prominent role in conflict management in Africa than ever before.

One of the implications of this more assertive African posture is that the UN has less freedom to manoeuvre than it enjoyed in the past. A decade and half ago the UN was the most important actor when it came to the deployment of peace operations in Africa. Today, it is unthinkable that the UN would consider deploying a new peace operation in Africa without close consultation with the AU and relevant African countries and sub-regional organisations. In fact, the UN would probably only consider deploying a peace operation in Africa if the AU or the relevant sub-region is unable to take the lead itself, and even then the UN mission is likely to have a significant African character. Africa is thus no longer only the recipient or host of UN peace operations, the AU and the sub-regional organisations in Africa have now become an integral part of the global peace and security architecture. This has changed the role of UN peace operations in Africa. As approximately $75 \%$ of UN peacekeepers are deployed in Africa, and approximately the same amount of the UN peacekeeping budget is spent on peace operations in Africa, this means that these changes are likely to profoundly affect UN peace operations in the years ahead.

This chapter will explore the future direction that AU and Africanled peace operations may take, and consider its impact on the strategic 
relationship between the UN and the AU. We will assess the capacities the $\mathrm{AU}$ has developed to date, and are likely to continue to develop, as well as several decisions the AU has taken recently regarding reorganising the Union and improving the way its peace operations are financed. Based on these considerations we will assess the implications of these developments for the relationship between the UN and regional organisations.

\section{African-Led Peace Operations}

The peace operations led by the AU, the Regional Economic Communities (RECs), Regional Mechanisms (RMs) or African-led ad hoc coalitions, are all deployed under the legal framework of the AU Constitutive Act and the UN Charter. The AU's Peace and Security Protocol have established a comprehensive African Peace and Security Architecture (APSA), which include elements such as the Continental Early Warning System, the Panel of the Wise, the Peace Fund, and the African Standby Force (ASF). Three RECs, namely the Economic Community of West African States (ECOWAS), the Economic Community of Central African States (ECCAS) and the Southern African Development Community (SADC), and two RMs, namely the East African Standby Force (EASF) and the North African Regional Capacity (NARC), make up the five regional standby arrangements of the ASF.

The practice that has emerged over the past decade and a half is that there are three main types of African-led peace operations, namely those deployed by the AU, those deployed by RECs/RM and those undertaken by an ad hoc coalition (de Coning 2017). The AU-led operations include the operations in Burundi (AMIB, 2003), Darfur (AMIS, 2004), Comoros (MAES, 2007), Somalia (AMISOM, 2007-), Mali (AFISMA, 2012), and the Central African Republic (CAR) (MISCA, 2013). The AU has also deployed a mission to West Africa to stop the spread of Ebola in 2014 (ASEOWA).

Examples of REC/RM-led operations include ECOWAS' ECOMOG missions in Liberia and Sierra Leone in the 1990s, the ECCAS missions in CAR, such as FOMUC (2002-2008) and MICOPAX (2008-2013), and the more recent ECOWAS missions to Guinea-Bissau and the Gambia (2017) and the SADC mission to Lesotho (2017).

Examples of African-led ad hoc security coalitions operations include the Regional Cooperative Initiative against the Lord's Resistance Army 
(RCI-LRA), the Multinational Joint Task Force (MNJTF) that is combatting Boko Haram in the Lake Chad Basin, and the G5 Sahel Force that combats violent extremism and organised crime in the Sahel. These coalitions differ significantly from the traditional notion of a peace operation. The MNJTF is essentially a counter-insurgency and counterterrorism operation where countries from the region, including Cameroon, Chad, Niger, and Nigeria undertake their own national operations-mostly within their own borders, and occasionally in hot pursuit across their borders-but in a coordinated manner with a shared political-strategic mandate and a joint multinational headquarters that coordinate the overall effort. The G-5 Sahel Force follows the same logic and is a regional initiative consisting of Chad, Burkina Faso, Mauritania, Mali, and Niger. Together they counter transnational organised crime and violent extremism in the Sahel region. The AU's role is to provide strategic-political direction and authority, via mandates from the Peace and Security Council (PSC), to coordinate international backing, including financial contributions, and to provide technical support for the multinational headquarters.

The observations and recommendations of the UN's Independent High-level Panel on Peace Operations (HIPPO) regarding the primacy of politics is also highly relevant for African-led peace operations. These African-led peace operations are meant to be part of a larger political intervention where the role of the military operation is to contain violence and generate stability, so that political solutions can be pursued. In reality, however, the security effort is often not matched sufficiently with political and development efforts. It often takes a few years for those responsible for deploying such operations to realise that the military or security dimension is insufficient to bring about and end to hostilities, and that a much more comprehensive approach is needed to sustain the peace. In Somalia, for instance, where AMISOM is engaged in stabilisation, counter-insurgency, and counter-terrorism operations, it took the $\mathrm{AU}$ and the Troop Contributing Countries (TCCs) approximately a decade to understand that whilst AMISOM may be able to temporarily stabilise a situation by winning selected battles and by controlling some towns, it cannot ultimately defeat Al Shabaab militarily. They can only be defeated in the long-term if the Government of Somalia can provide better security, governance, and social-economic opportunities than what $\mathrm{Al}$ Shabaab can offer. As a result of these lessons, there are initiatives underway in the Sahel and Lake Chad Basin to embed the G5 force and the 
MNJTF into larger regional stabilisation strategies that are politically-led and that include development, socio-economic, governance and rule of law dimensions. It also means that these African-led operations would need to be part of larger international networked stabilisation and development strategies, because they would not be able to achieve their missions on their own. The UN plays a leading role in coordinating these regional strategies and networks.

Most AU- and REC-led peace operations to date have included political and civilian components that have the task of providing the mission leadership with advice and support on the roles these missions should play in the political and civilian realms, as well as in participating in the larger regional and international networks that are needed to achieve their missions' mandate. The ASF has had a dedicated effort to develop the civilian dimension of African peace operations since 2006 (de Coning and Kasumba 2010). However, these efforts have lagged behind the investment in the military capabilities of the ASF, and will need to be significantly scaled-up if they are going to have an impact on the way AU- and REC-led peace operations are planned and managed (de Coning et al. 2017). The UN has been slow to grasp the importance of the civilian dimension of African peace operations. Initially the UN has discouraged the AU from developing a civilian component for, for instance AMISOM. It saw AMISOM as a military operation and it wanted the UN political mission to provide the civilian expertise. Eventually the UN accepted that the AU needed to have its own political and civilian expertise in order for it to meaningfully engage in a larger comprehensive strategic framework (de Coning et al. 2017).

Two other operations deserve to be mentioned, because the first reflects how African-led capabilities have also augmented UN peace operations and the second reflects on the level of maturity the African peace and security architecture. The first is the Force Intervention Brigade (FIB) that was deployed to enhance the UN Stabilization Mission to the Democratic Republic of the Congo (MONUSCO) in 2013. The FIB was given the mandate to neutralise the M23 and other rebel groups, and is a rare example of a UN peace operation that has been tasked to do peace enforcement (Karlsrud 2015). The International Conference on the Great Lakes Region (ICGLR), SADC, and the AU concluded that MONUSCO was not effective enough in countering the M23 and other rebel groups in Eastern DRC, and proposed to establish an AU or SADC force. Once the UN Security Council was convinced that such a force had clear political support from all the stakeholders in 
the region, the UN suggested that such a force should be incorporated into the existing UN mission. This was agreeable to the countries in the region because it resolved the complications that would arise from having two different forces operating in the same area of operations, and it also solved the challenge of financing and supporting the FIB if it was an AU or SADC operation.

The FIB is widely regarded as having been effective in supporting the Congolese armed forces in containing the M23 rebel group (Peter 2015). This success was due to a number of factors. All the FIB's TCCs-Malawi, South Africa, and Tanzania-as well as the host nation DRC, are members of SADC. They have participated in joint training exercises under the auspices of the SADC Standby Arrangement of the ASF, which meant that they had a common understanding of the doctrine and command and control. The FIB was deployed with a clear political will to use force. With the full support of the DRC, TCCs, SADC, ICGLR and the AU, the UN Security Council deployed the FIB with a clear mandate to use offensive force, if necessary, to contain the rebel groups. Finally, the FIB was deployed with its own enablers and force multipliers including artillery, attack helicopters, and specially trained troops. It is the combination of these factors that enabled the FIB to undertake the kind of offensive enforcement actions that it did initially take against the M23. When some of these factors waned, for instance when the DRC, TCCS, ICGLR, SADC, the AU and the UN failed to reach a similar common understanding on how best to deal with some of the other rebel groups, the FIB became less effective.

As a result of the early successes of the FIB in the DRC, the AU and UN also considered deploying an African FIB-type mission to Northern Mali, and a Regional Protection Force in Juba, South Sudan, which would be tasked with protecting civilians to support the UN Mission in South Sudan. The protection force was authorised in August 2016, but deployment began first in August 2017 because the government of South Sudan objected to its composition and deployment modalities (Williams 2016). The plan for a FIB-type mission for Northern Mali morphed into what is now the G-5 Sahel Force. These developments may indicate the start of two news trends, namely on the one hand where regionally led and composed forces are used to augment UN peacekeeping operations, and on the other hand, where UN peacekeeping or dedicated support missions are used to support regional forces, such as in the case of AMISOM and the G5-Sahel force. 
The second operation is the January 2017 intervention of ECOWAS in The Gambia. In this case a constitutional crisis developed when the then President Yahya Jammeh, first recognised and then later disputed the victory of Adama Barrow in the 2016 presidential election. ECOWAS, the AU, and the international community recognised the outcome of the 2016 presidential election. A constitutional crisis loomed as President Jammeh refused to step down and hand over power on 19 January 2017 (Al Jazeera 2017). To avert a crisis, several heads of state from the ECOWAS region travelled to The Gambia to convince Jammeh to hand over power. When he continued to refuse, ECOWAS prepared for a military intervention. On 19 January, Adama Barrow was inaugurated as President in the Gambian Embassy in Senegal. His first act at President was to request ECOWAS to help ensure that the constitutional order is preserved in The Gambia. On the same day the UN Security Council approved Resolution 2337, which expressed support for ECOWAS' efforts to find a political solution to the crisis in The Gambia. Shortly before the ECOWAS Mission in The Gambia (ECOMIG) started to enter The Gambia from neighbouring Senegal, the Gambian army chief pledged allegiance to President Barrow and declared that the Gambian army will not resist the ECOWAS intervention. Before ECOMIG reached the capital Banjul, it halted its advance to give more time to find a negotiated solution. After further diplomatic interventions by the Presidents of Mauritania and Guinea, Jammeh finally agreed to step down, and he left the country on 21 January (Cocks and Jahateh 2017).

As President Barrow requested help from fellow ECOWAS countries, ECOMIG was not a non-consensual intervention, and thus did not require UN Security Council authorisation. The Gambian experience reflects how far ECOWAS and the AU has come in the development and application of the APSA. Firstly, ECOWAS and the AU followed the election in The Gambia closely, including through election observation missions, and thus had their own information that led them to credibly recognise the outcome of the elections. Secondly, both ECOWAS and the AU took several decisions that signalled very clearly to Jammeh and the international community their intent to recognise the election and thus Barrow as the elected President. ECOWAS signalled early that it would pursue a peaceful transfer of power, but use force if necessary. The AU also clearly signalled that it would no longer regard Jammeh as President after 19 January. The AU has a long-standing policy to reject 
unconstitutional changes of government, and the consistent application of this norm further helped to create a political context in which it was clear to all, and finally also to Jammeh, that he had no option other than to hand over power to newly elected President Barrow. Thirdly, the mustering of ECOMIG signalled to Jammeh, the Gambian army, and all others involved that ECOWAS was serious in its intent to use force if necessary. Fourthly, ECOWAS was careful to ensure that it acted according to international law and the constitution of The Gambia, further ensuring that the mission was seen by all as legitimate and credible. Lastly, ECOMIG managed to intervene with a credible mustering of force and firm resolve, carefully synchronised with clear political support and direction, and this enabled it to achieve its mission without the need to use force. The Gambia case demonstrated how ECOWAS and the AU used its political, diplomatic, and military tools in a sophisticated and coordinated way to prevent and manage a significant crisis. The alternative could have been a costly civil war that could have destabilised an already fragile region.

The AU and the sub-regional organisations have thus developed a significant peace operations capacity over the last decade and a half. This capacity has been used to deploy AU, sub-regional and ad hoc coalition operations, and it has contributed significantly to UN peace operations. At the same time, as the Gambia case show, African institutions have developed the ability to coordinate sophisticated international, regional and sub-regional networks, as well as to align its political, diplomatic and peace operations efforts, to prevent and manage crisis and conflicts. African is thus no longer only a recipient or host of UN peace operations, but it has now become a strategic partner and enabler for the UN.

\section{AU REForms}

There are three aspects that will have a significant impact on the future direction of African-led peace operations. Firstly, the AU should adapt its current Peace Support Operations (PSO) doctrine, as well as the ASF concept, to better reflect the kind of operations the AU and RECs have undertaken over the past decade, and is likely to undertake in future. The AU PSO doctrine and ASF concept was developed between 2003 and 2008, when the AU had little experience of its own. As a result, its PSO doctrine and ASF concept largely reflect the doctrinal and policy assumptions of NATO, EU, and the UN at the time. Since then, a 
unique African model of peace operations has emerged (de Coning et al. 2016), and NATO, EU, and UN approaches to peace operations have also undergone considerable adaptations (de Coning et al. 2017). The AU should thus review and update its doctrine, concepts and policy frameworks to reflect the changes in the global system and its own experiences and lessons.

Secondly, another important aspect that needs to be addressed is the ambiguous relationship between the AU and the RECs. Various AU reports and decisions have highlighted the need to clarify the relationship between the AU and the RECs (African Union 2017; Assogbavi 2017). Should the relationship be based on the principle of subsidiarity, where the RECs have the primary responsibility for peace and security in their regions? There are two issues that complicate this question. Firstly, how should the AU and RECs deal with crises that lie on the border of two regions? Secondly, how should the response account for the fact that not all regions are equally developed?

The AU operation in Mali has highlighted the challenges when a REC, in this case ECOWAS, has to manage a crisis on its border, when key neighbours and stakeholders, for instance Algeria and Chad, are not part of the REC. In such instances the role of the AU can be a key factor in ensuring regional coherence and synergy. The operation in Mali also highlighted that in the absence of a functioning REC in North Africa, the AU had to go beyond the regional building block model and find innovative ways to engage all the stakeholders. The planning for the 2016 MAPROBU mission in Burundi also showed that although the Eastern African Standby Arrangement should have been the appropriate regional mechanism to carry out the mission, various political factors resulted in the AU having to look beyond the regional building block model for TCCs. These cases show that the AU cannot always depend on the subsidiarity-based REC regional building-block model of the ASF. In fact, despite the progress made with the ASF, most African-led operations to date have been ad hoc coalitions of the willing (de Coning et al. 2016, p. 120). The AU-REC/RM experiences in Burundi, CAR, Mali and Somalia have thus shown that each situation is unique and that no one model of subsidiarity can accommodate each situation. Instead, in each case, a particular division of work emerged based on the actual relations and comparative advantages of the different actors on the ground. Instead of trying to find one predictable model, the AU and RECs/RMs should invest in institutionalising predictable coordination 
and cooperation mechanisms and processes, including regular information exchanges, joint assessment missions, joint analysis, joint planning, joint deployments, co-location, and joint evaluations.

Thirdly, the AU has decided to embark on a significant structural reform process during its January 2017 Summit, based on a set of proposals submitted by a team led by President Paul Kagame of Rwanda (Assogbavi 2017). The reform proposals require that the AU refocus itself around fewer priorities, of which peace and security is recognised to be at the core of the AU's mandate and role. Another important dimension is the financing of the African Union and specifically the funding of peace operations.

The AU has become reliant on partners for approximately $98 \%$ of its programme budget and $99 \%$ of its peace and security expenditure (African Union 2016a). This is problematic, because the AU's dependency on external resources denies it the freedom to independently take decisions on the strategic, operational, and even tactical aspects of the PSO it is responsible for. Any action that has cost implications requires prior negotiation with partners to mobilise the resources necessary for it to be implemented. As a result, the AU has only been able to undertake those operations where there was a convergence of interests with its partners.

The financial problems of the AU reached a critical stage in 2015, and that year the AU Member States, at both the January and July AU Summits, committed themselves to self-finance $100 \%$ of the AU's regular budget, $75 \%$ of its programme budget, and $25 \%$ of its peace and security budget, in particular the cost of its peace operations, by the year 2020 (African Union 2016a). This commitment was followed-up at the AU Summit in Kigali in June 2016, where a historic decision was reached to implement a $0.2 \%$ levy on eligible imports into all AU member states (African Union 2016b, para. 5b). In addition to the decision to introduce an import levy, the July 2016 Summit also approved recommendations for the revitalisation of the Peace Fund.

If successful, this new funding arrangement will significantly strengthen the ability of the AU to take ownership of its own operations. It will also result in a more balanced relationship between the AU and the UN, because the AU will be able to co-fund-with at least $25 \%$ of its operations - those peace operations the UN Security Council authorises it to undertake. The funding generated by the import levy may enable the AU to shift its relations with partners away from one defined by financial necessity, to one informed by strategic choice. 
There are thus reforms underway at the level of the AU and the RECs that has the potential to further strengthen the capacity of the AU and RECS/RMs to undertake peace operations. The AU-UN relationship is thus likely to be characterised by a further strengthening of African capabilities and a willingness of African institutions to take up an even greater share of responsibility for African peace and security.

\section{Implications for the Strategic Partnership With THE United Nations}

The AU-UN relationship used to be more like a donor-recipient relationship where the UN's role was to build the capacity of the AU. The AU took a conscious decision to change that a decade and a half ago, and have since succeeded in transforming the AU-UN relationship into a functioning strategic partnership.

The peace operations that the AU undertakes under UN authorisation needs to be understood as regional responses to global problems. Most African conflicts are global in the sense that they are heavily influenced by external factors like the global war on terror; fall-out and spillover from the interventions in Iraq, Afghanistan, Libya, and Syria; the exploitation of natural resources by multinational companies; capital flight facilitated and solicited by the international financial system; and transnational organised crime, driven by markets in the West and Asia for narcotics, human trafficking, timber, and illegally caught fish (Africa Progress Report 2013). African peace operations thus represent a significant contribution to the global common good.

For this reason, the AU has been arguing consistently for many years that, together with other regional organisations, it is effectively part of a collective global peace and security architecture. Therefore, when the AU is asked to help the UN maintain international peace and security in Africa, the UN should use its assessed contribution system to support the peace operations that the AU is undertaking on behalf of the UN (African Union 2016a). From an AU perspective, the UN assessed contribution budget for peace operations is the most effective and efficient global burden-sharing arrangement for peace operations, as all members of the international system contribute to the budget against a preagreed scale of assessment. However, to date, the prevailing view in the UN Security Council is that the UN should assist the AU to mobilise resources by encouraging partners and by facilitating the establishment 
of Trust Fund arrangements, but that its obligation does not extend to directly financing AU operations. However, in Sudan, Mali, CAR and Somalia the UN Security Council has authorised, on a case-by-case basis, the UN to assist AU peace operations with various form of direct and indirect support, utilising the UN's assessed contribution budget. The issue that is currently being considered is whether the UN Security Council should make an in-principle commitment to finance AU peace operations.

In this debate a number of pre-conditions have been identified, namely that the AU take steps to ensure that its peace operations adhere to international human rights, international humanitarian law, and related conduct and discipline standards, that the AU provide access to UN auditors, and that the AU finances at least 25\% of the cost of its peace operations itself. The AU has taken steps towards meeting these pre-conditions, and the UN Secretariat and a number of UN Member States have expressed satisfaction with the progress made. It is likely that the AU, the UN Secretary-General and several UN Member States will keep this issue on the agenda of the UN Security Council, but it is unlikely that the Council will commit itself in-principle, to directly financing AU peace operations authorised by the UN Security Council in the short- to medium term.

At the UN a number of reforms are also underway, and there is thus a need for the AU and UN to remain closely coordinated, at all levels, to ensure that both can adapt their relations to their respective reform processes, as well as in response to the existing and emerging operational challenges they face.

Meanwhile, at the operational level, a symbiotic division of work has developed between the AU and the UN, and this has been further strengthened in a strategic partnership agreement between the AU and UN that was signed in 2017. The UN is good at implementing peace agreements and consolidating peace processes, but it is not well suited for enforcement actions. The AU has demonstrated that it is willing and able to undertake stabilisation and counter-terrorism operations, but it lacks the broad sets of capacities necessary to implement comprehensive peace agreements. The UN and AU thus have mutually reinforcing capabilities that serve as the basis for a strategic partnership in which the UN and AU complement and augment each other. The AU and sub-regional organisations have acted as first responders in Burundi, CAR and Mali. When these situations have been sufficiently stabilised, the UN has taken 
over with a peacekeeping operation to consolidate the peace. In Burundi, CAR, and Mali, the African military and police personnel that served in the AU operations were re-hatted and became UN peacekeepers. In other cases, like Somalia, where the UN Security Council has authorised enforcement, the AU has deployed and managed the operations, but with financial and logistical support from the UN and other partners.

At the strategic level, the UN and the AU need to foster a common narrative that is mutually re-enforcing and respectful of each other's roles and comparative advantages. The members of the UN Security Council and the AU's PSC have started to meet regularly. However, these kinds of meetings need to be further deepened so as to ensure even greater coherence between the approaches of the UN Security Council and the AU PSC on the many conflicts that are on their mutual agenda.

At the operational level, the UN and AU have been meeting regularly at the desk-to-desk level, but these meetings now need to start delivering specific outcomes, such as developing guidelines for joint assessments, shared analysis, joint planning, AU-UN inter-mission coordination and cooperation, mission support, best practices, join evaluations, and joint Standard Operating Procedures for transitions between AU and UN operations.

Almost all AU peace operations will be accompanied by UN special political missions, similar to the way UNSOM and AMISOM have operated side-by-side in Somalia. At the same time, most UN peacekeeping operations in Africa will be accompanied by AU special political missions, such as has been the case with MINUSMA and African Union Mission for Mali and Sahel (MISAHEL) in Mali and MINUSCA and AU Mission for the CAR and Central Africa (MISCA) in CAR. A set of pre-agreed joint guidelines will make it easier for both organisations to involve each other from the earliest stages in assessments, planning, coordination mechanisms, mission support, benchmarks, and evaluation. This is especially important in those cases where AU peace operations transition into UN peacekeeping operations, or vice versa.

One of the AU's serious challenges is the capacity to support its own operations. The AU lacks a mission support concept and the staff/ personnel, systems, and resources necessary to implement such a concept. The AU, with the support of the UN, has embarked on a process to develop a mission support policy. It will take several years for the AU to develop and refine its missions support capacity, and in the meantime it will rely on the UN and partners to support its operations. 
This is especially challenging when the AU needs support for stability, counter-insurgency, and counter-terrorism operations-all peace enforcement operations in UN context-whilst its main partner in this regard, the UN, is geared to provide support to peacekeeping operations. Both institutions will need to develop fixes to cover this gap, until the AU has developed its own capacity in this area.

The AU and the UN has developed a functioning strategic partnership. This partnership plays out at the political, policy and operational levels, and reflect the reality that neither the AU nor the UN will deploy peace operations in Africa without close consultations and some form of cooperation with each other.

\section{Conclusion}

In this chapter, we explored the major factors that are likely to influence the future direction that African-led PSO may take, and considered what the impact may be of these developments for the strategic partnership between the UN and the AU. We argued that Africa's peace operations capacity has significantly increased over the past decade and a half because the AU, with significant support from the UN and its other partners, have invested in establishing and developing the ASF. As a result of this investment, Africa is now the largest regional contributor to UN peace operations.

When the ASF was designed, the AU had little peace operations experience of its own. Over the last decade the AU has undertaken eight operations of its own and has supported several others. In addition to contributing troops and police officers to UN peacekeeping missions, African countries are also likely to continue to provide African-led stabilisation brigades to augment UN peacekeeping missions in contexts like Mali and South Sudan, drawing on the success of the FIB model used in the DRC.

One of the implications of the significant capabilities that the AU and African sub-regional organisations have developed, is that the UN can no longer deploy peace operations of its own in Africa, without at least close consultations with the AU and sub-regional bodies. This is, however, not seen as a negative development. The increased capacity and willingness of the AU and other African regional bodies and coalitions to play an even greater role in African peace and security is seen as a positive development that opens the door for more specialisation, based on comparative 
advantage, as well as greater burden sharing. As discussed in several other chapters in this book, many of the challenges facing UN peace operations relate to the fact that the UN peacekeeping model is not well suited to enforcement or counter-terrorism type operations. Nor is the UN peacekeeping model well suited to deal with transnational challenges such as organised crime or regional manifestations of, for instance, violent extremism. The AU and other African bodies, such as the MNJTF in the Lake Chad Basin or the G5 force in the Sahel seem to be better suited to address these kinds of challenges. These African capabilities thus help to relieve the pressure on the UN on some fronts, which enable it to re-focus its efforts in other areas.

In the context of the larger shifts underway in the global order, the emerging role of African-led peace operations in Africa-where it has taken on a significant portion of the peace and security burden that the UN would otherwise have had to carry on its own-raises the question whether a new global peace and security architecture is emerging? In the past, Chapter VIII of the UN Charter, that deals with regional arrangements, was understood as providing for exceptional cases where the UN may need to turn to a regional organisation for help. As a result of the role the AU plays in Africa-and the European Union (EU) plays in Europe-the question arises whether the UN and regional organisations should establish a more formal global peace and security architecture that is based on burden-sharing and the principle of subsidiarity. This means that threats to international peace and security should be dealt with at the most immediate (or local) level that is consistent with their resolution.

At the moment, the relationships between the UN and regional organisations are undefined. Although the primary responsibility of the UN Security Council is not questioned, this does not amount to a hierarchal system where regional organisations such as the AU or the EU are subsidiary parts of a global peace and security architecture. Such an architecture would have a pre-agreed division of roles and responsibilities, where regional organisations are responsible for maintaining peace and security in their own regions, and where the UN is responsible for those aspects of international peace and security that the regional organisations are not able to address, or that is trans-regional. Rather, at present, the UN and regional organisations co-exist in a loosely defined manner that requires voluntary coordination and causes both tension and competition. A global peace and security architecture approach 
would imply that the UN and regional organisations, like the AU, agree to a more clearly defined division of roles under a burden-sharing arrangement. Such predictability would enhance cooperation, coordination, and efficiency and significantly alter the way we understand the role of the UN and regional organisations like the AU in the global peace and security architecture.

\section{REFERENCES}

Africa Progress Report. 2013. Equity in Extractives: Stewarding Africa's Natural Resources for All. Geneva: Africa Progress Panel.

African Union. 2016a. Securing Predictable and Sustainable Financing for Peace and Security in Africa. Addis Ababa: African Union.

African Union. 2016b. Decision on the Outcome of the Retreat of the Assembly of the African Union, July. Addis Ababa: African Union.

African Union. 2017. The Imperative to Strengthen Our Union: Report on the Proposed Recommendations for the Institutional Reform of the African Union. Addis Ababa: African Union.

Al Jazeera. 2017. New Gambia President Adama Barrow Takes Oath in Senegal, Doha. Al Jazeera, January 19.

Assogbavi, D. 2017. Key Decisions of the AU Summit. https://assodesire. com/2017/01/31/key-decisions-of-the-au-summit/. Accessed 5 Feb 2018.

Cocks, Tim, and Lamin Jahateh. 2017. Gambia's Former Leader Jammeh Flies into Exile in Equatorial Guinea. Reuters, January 21.

de Coning, Cedric. 2017. Peace Enforcement in Africa: Doctrinal Distinctions Between the African Union and United Nations. Contemporary Security Policy 38 (1): 145-160.

de Coning, Cedric, and Yvonne Kasumba. 2010. The Civilian Dimesion of the African Standby Force. Durban: ACCORD and the African Union.

de Coning, Cedric, Linnea Gelot, and John Karlsrud. 2016. The Future of African Peace Operations: From Janjaweed to Boko Haram. London: Zed Books.

de Coning, Cedric, Chiyuki Aoi, and John Karlsrud. 2017a. UN Peacekeeping Doctrine in a New Era. London: Routledge.

de Coning, Cedric, Irene Limo, James Machakaire, and Jide M. Okeke. 2017b. The Role of the Civilian Component in African Union Peace Operations. In The African Standby Force-Quo Vadis? ed. Francois Vrey and Thomas Mandrup. Stellenbosch: Sun Media.

Karlsrud, John. 2015. The UN at War: Examining the Consequences of PeaceEnforcement Mandates for the UN Peacekeeping Operations in the CAR, the DRC and Mali. Third World Quarterly 36: 40-54. 
Lotze, Walter. 2013. Strengthening African Peace Support Operations: Nine Lessons for the Future of the African Standby Force. Berlin: German Peace Operations Center (ZIF).

Peter, Mateja. 2015. Between Doctrine and Practice: The UN Peacekeeping Dilemma. Global Governance 21: 351-370.

United Nations. 2018. Peacekeeping Fact Sheet. www.un.org/en/peacekeeping/resources/statistics/factsheet.shtml. Accessed 12 Mar 2018.

Williams, Paul. 2016. Key Questions for South Sudan's New Protection Force. New York: IPI Global Observatory.

Open Access This chapter is licensed under the terms of the Creative Commons Attribution 4.0 International License (http://creativecommons.org/licenses/ by $/ 4.0 /$ ), which permits use, sharing, adaptation, distribution and reproduction in any medium or format, as long as you give appropriate credit to the original author(s) and the source, provide a link to the Creative Commons license and indicate if changes were made.

The images or other third party material in this chapter are included in the chapter's Creative Commons license, unless indicated otherwise in a credit line to the material. If material is not included in the chapter's Creative Commons license and your intended use is not permitted by statutory regulation or exceeds the permitted use, you will need to obtain permission directly from the copyright holder.

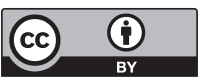

